

\title{
ASSESSMENT OF NUTRITIONAL STATUS AND KNOWLEDGE OF STUDENTS FROM SELECTED SECONDARY SCHOOLS IN SOKOTO METROPOLIS, SOKOTO STATE, NIGERIA
}

\author{
Essien $\mathrm{E}^{1 *}$, Emebu $\mathrm{PK}^{2}$, Iseh $\mathrm{KR}^{3}$ and MJ Haruna ${ }^{4}$
}

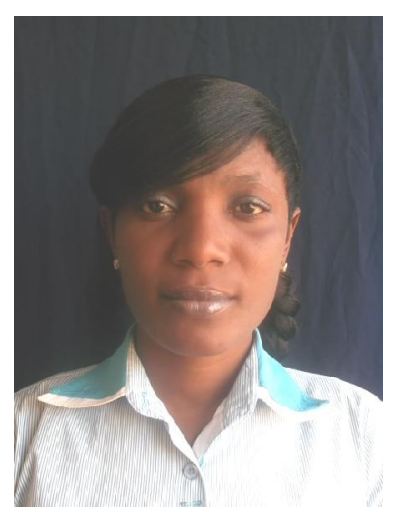

Essien Eno

*Corresponding author email: blessedgift2007@yahoo.com

${ }^{1}$ Department of Community Medicine, Nutrition and Dietetic Unit, Usmanu Danfodiyo University Teaching Hospital, PMB 2370, Sokoto, Nigeria

${ }^{2}$ Department of Biochemistry, Usmanu Danfodiyo University, Sokoto, Nigeria

${ }^{3}$ Department of Otorhinolaryngology, Usmanu Danfodiyo University Teaching Hospital, Sokoto

${ }^{4}$ Shehu Shagari College of Education, Sokoto, Nigeria. 


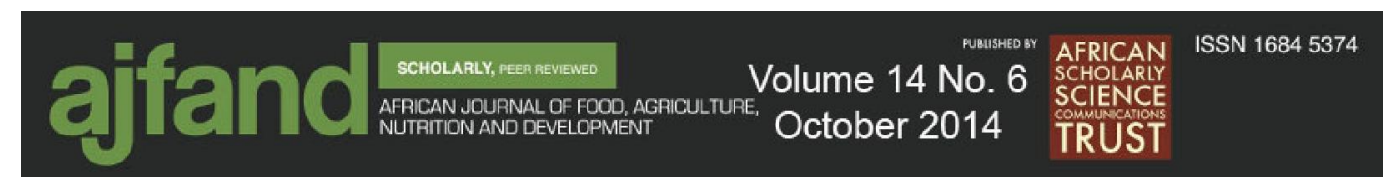

\begin{abstract}
The significance of improving nutrition knowledge in order to have a positive influence on food choices and health should not be underestimated. This study assessed the nutritional status and knowledge of school children attending selected secondary schools in Sokoto metropolis. The study population was purposively drawn from secondary school students in Nigeria attending Federal Government College and State Government-owned schools. Four secondary schools were used for the study: Federal Government College (FGC), Sani Dingyadi Secondary School (SDUSS), Nagarta Secondary School (NSS) and Army Day Secondary School (ADSS). A sample of 240 school students, aged 10 to 25 years participated in the study. The measuring instruments included a questionnaire to determine the nutrition knowledge of the students. Anthropometric measurements included weight, height and mid-upper arm circumference, measured using standard methodologies. The mean age recorded for male and female students were $18.0 \pm 1.90$ and $15.7 \pm 1.20$ years, respectively. The result showed that $27.9 \%$ were underweight, $7.5 \%$ overweight and $64.6 \%$ had normal BMI status. Nutritional status was significantly related with sex $\left(\chi^{2}=16.169, p<0.05\right)$ but not with age $\left(\chi^{2}=1.368, \mathrm{p}>0.05\right)$. The prevalence of underweight was higher among the males $(33.9 \%)$ compared to the females $(13.9 \%)$, while more females were overweight $(15.3 \%)$ compared to the males $(4.2 \%)$. Seventy one percent performed poorly in the nutrition knowledge assessment rating. The overall performance of the female students was significantly higher $\left(\chi^{2}=46.386 ; \mathrm{P}<0.05\right)$ than their male counterparts. Furthermore, 5, 12 and $12 \%$ had excellent, very good and good nutrition knowledge, respectively, while $33 \%$ and $38 \%$ had fair and poor nutrition knowledge, respectively. The results further revealed that the students were deficient in knowledge and understanding of the facts about energy and nutritive values of foods. Therefore, adequate nutrition education is needed at the secondary school level; this will enable the students to make good food choices and positively influence their eating habits thereby ensuring better nutritional status.
\end{abstract}

Key words: malnutrition, knowledge, school, anthropometry, Sokoto 


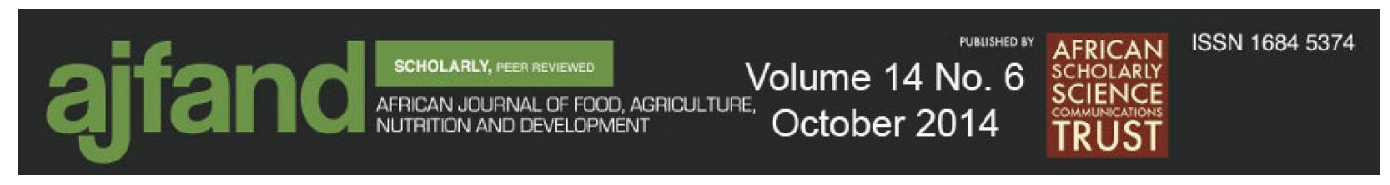

\section{INTRODUCTION}

Malnutrition has an effect on children's wellbeing and their ability to learn and play normally. Indeed, healthy food choices improve a child's wellbeing and ability to learn and play normally [1]. Dietary habits in childhood impact growth, development and the prevalence of disease throughout the life cycle. Healthy eating habits should thus be established during childhood [2]. The quality of diet declines as children move from childhood to adolescence. Eating healthy is not a priority for adolescents. Poor eating patterns may thus add a risk for current and future health problems [3]. A large number of school-based nutrition programmes have been implemented globally, focusing mainly on obesity, the importance of activity and of vegetables and fruit in the diet [4]. However, little research on basic nutrition education focusing on adolescents has been published [5]. The significance of improving nutrition knowledge through nutrition education in order to have a positive influence on healthy food choices should not be underestimated $[6,7]$.

The aim of this study was to determine the nutrition knowledge and nutritional status of children attending a secondary school in Sokoto metropolis. This was done in order to gain information for planning a nutrition education programme, as poor knowledge of nutrition is seen as one of the reasons for poor food choices [8] and, consequently, as a contributing factor in the development of malnutrition [9].

\section{MATERIALS AND METHODS}

This study was a descriptive survey involving secondary school students comprising male and females aged 10-25 years. The study was conducted in Sokoto Metropolis, Sokoto State, Nigeria. Sokoto Metropolis has 19 State Secondary Schools out of which nine (9) are boarding. Permission to carry out the study was obtained from the Ministry of Education, Sokoto State.

The study population was drawn from secondary school students attending Federal Government College and State Government-owned schools. A purposive sampling technique was used where the total number of schools used for the study as well as the total number of students from each school was purposively selected. The selected schools were: Federal Government College (FGC), Sani Dingyadi Secondary School (SDUSS), Nagarta Secondary School (NSS) and Army Day Secondary School (ADSS). A total number of 240 students, comprising 60 students from each school, participated in the study.

Data for the study were collected using a structured and validated questionnaire. The respondents were requested to select the appropriate options as it applied to them. Anthropometric measurements of weight and height of the children were carried out based on the standardized methods of WHO [10] and UNICEF [11]. The students were weighed on a bathroom scale wearing minimal clothing. Height was measured with a wooden height meter. Children were measured without shoes. Heads were erect and hands hanging at their sides in a natural manner. Readings were taken to the 


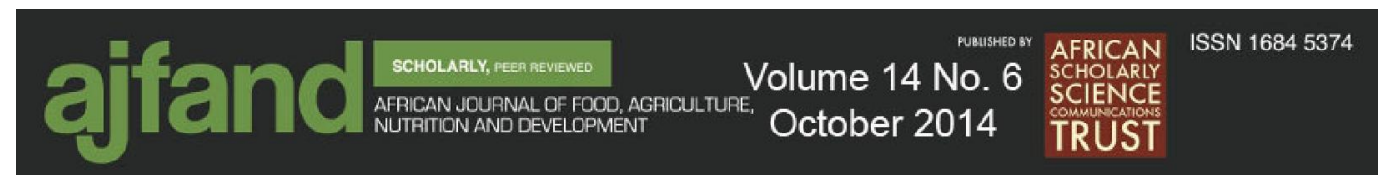

nearest $0.1 \mathrm{~cm}$. Height-for-age, weight-for-age and weight-for-height of each student were compared with WHO Growth standards.

The nutrition knowledge of the school children was assessed by the use of multiple choice questions set by the researcher to ascertain their level of knowledge of nutrition. The test comprised 12 nutrition knowledge questions. The nutrition knowledge scores of the students were graded as follows: Excellent (71-100), Very good (61-70), Good (51-60), Fair (41-50) and poor (0-40).

Data collection and editing were done manually. Data processing and analysis were done using Microsoft Excel and Statistical Package for Social Sciences (SPSS) for Windows, version 18.0 (Statistical Package for Social Sciences, Chicago, IL, USA). Statistical methods used were means, standard deviations, analysis of variance (ANOVA), frequency and percentages and chi-square test. Statistical significance was set at $\mathrm{P}<0.05$.

\section{RESULTS}

\section{Food consumption and eating habits}

Two hundred and forty (240) secondary school students comprising 168 males (70\%) and 72 females (30\%) participated in the study. The ages of the students ranged from 12 to 23 years with a mean age of $18.0 \pm 1.90$ years and $15.7 \pm 1.20$ years for males and females, respectively. The result of food consumption and eating habits of the respondents showed that more than half of the students $(56.3 \%)$ ate three times daily while $27.1 \%$ ate more than three times (Table 1). Meal skipping was high among the selected secondary school students as $68.8 \%$ reported that they skipped meals. Only $31.3 \%$ do not skip meals. The major reason for meal skipping was fasting/religious reasons $(57.1 \%)$. This observation could be attributed to the period in which the study was carried out. The study was carried out in the month of August, which happened to coincide with the Islamic Ramadan fasting period. Further, 20.4\% reported meal skipping as habitual, while dislike for the meal accounted for $15 \%$ of the reason for meal skipping. The major meal skipped by the students was breakfast $(40.4 \%)$ followed by lunch $(26.3 \%)$ and dinner $(21.7 \%)$, respectively. Snacking was also observed to be high among the students as $82.1 \%$ of the students reported that they consumed snacks. The students gave reasons for snacking such as like $(48.3 \%)$, hunger $(26.3 \%)$, habit $(13.8 \%)$ and to make up for skipped meals $(11.6 \%)$, respectively. The major source of snacks for the students was home $(33.3 \%)$, while $30.4 \%$ obtained their snacks from the school premises, $18.8 \%$ from outside school premises and $17.5 \%$ from food vendors.

\section{Anthropometric measures}

The mean weight of the students ranged from $49.4 \mathrm{~kg}$ for students of Nagata College Sokoto (NCS) to $53.6 \mathrm{~kg}$ for SDUSS students with significant difference $(\mathrm{P}<0.05)$ in the observed values (Table 2). Mean weight of ADSS and FGCS were $55.1 \mathrm{~kg}$ and $53.2 \mathrm{~kg}$, respectively. A global mean weight of $52.8 \mathrm{~kg}$ was recorded for the study. 
Students of SDUSS were significantly taller $(164.6 \mathrm{~cm})$ than students of the other selected schools. Army Day Secondary School (ADSS), FGCS and NCS had mean height values of $159.2,160.8$ and $159.7 \mathrm{~cm}$ respectively, although these differences were not statistically significant $(\mathrm{P}>0.05)$. With respect to mid upper arm circumference (MUAC), ADSS recorded the highest mean value $(21.7 \mathrm{~cm})$ which was not significantly different $(\mathrm{P}>0.05)$ from those of FGCS $(21.6 \mathrm{~cm})$ and SDUSS $(20.8 \mathrm{~cm})$, respectively. Nagata College Sokoto (NCS) students had the least MUAC value of $18.9 \mathrm{~cm}$. Body mass index (BMI), which is an index of nutritional status, was significantly different among students of the selected secondary schools. The overall mean BMI value was $20.3 \mathrm{~kg} \mathrm{~m}^{-2}$. Mean BMI value was highest in ADSS $\left(21.7 \mathrm{~kg} \mathrm{~m}^{-}\right.$ ${ }^{2}$ ) followed by FGCS $\left(20.6 \mathrm{~kg} \mathrm{~m}^{-2}\right)$. NCS and SDUSS had mean BMI scores of 19.3 and $19.8 \mathrm{~kg} \mathrm{~m}^{-2}$, respectively.

\section{Nutritional status}

Results showed that $27.9 \%$ were underweight, $7.5 \%$ overweight and $64.6 \%$ had normal BMI status (Table 3$)$. Nutritional status was significantly related with sex $\left(\chi^{2}\right.$ $=16.169, \mathrm{p}<0.05)$ but not with age $\left(\chi^{2}=1.368, \mathrm{p}>0.05\right)$. The prevalence of underweight was higher among the males $(33.9 \%)$ compared to the females $(13.9 \%)$, while more females were overweight $(15.3 \%)$ compared to the males $(4.2 \%)$.

\section{Nutrition knowledge}

Twenty nine percent had good nutrition knowledge while $71 \%$ performed poorly (Fig. 1). The overall performance of the female students was significantly higher $\left(\chi^{2}=\right.$ 46.386; $\mathrm{P}<0.05$ ) than that of their male counterparts (Fig. 2). This was revealed by the higher percentage of female than male students who had excellent nutrition knowledge scores ( 8.3 vs. $4.2 \%$ ), very good nutrition knowledge scores (25 vs. $6.5 \%$ ) and good nutrition knowledge scores ( 25 vs. 6.5\%). However, more males than females had fair (34.5 vs. $27.8 \%$ ) and poor (48.2 vs. $13.9 \%)$ nutrition knowledge scores, respectively.

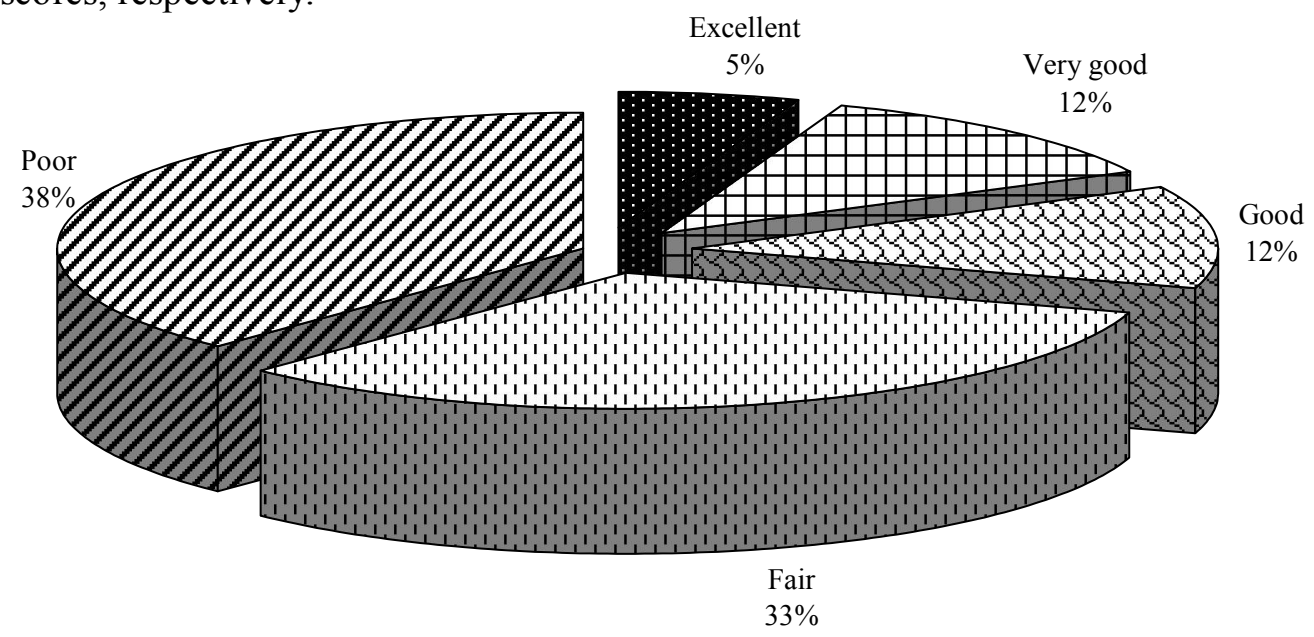

Figure 1: Nutrition knowledge of secondary school students from selected schools in Sokoto Metropolis 



Figure 2: Nutrition knowledge rating of male and female secondary school students from selected schools in Sokoto Metropolis $\left(\chi^{2}=46.386 ; d f=\right.$ 4; $P=0.000)$

\section{Response to nutrition knowledge assessment questions}

Multiple-choice questions were used in the assessment. Generally, there were significant differences $(\mathrm{P}<0.05)$ in the responses of the selected secondary school students to questions $1,3,5,6,10,11$ and 12 (Table 4). The students had better performance in their response to questions 1,5 and 12 having total scores above $60 \%$. However, the responses to question 2 (green leafy vegetables contain more of?) and question 11 (which food group provide the best source of energy?) is a cause for concern because the correct scores obtained were below $20 \%$ (17.5\% for question 2 and $11.7 \%$ for question 11 ).

\section{DISCUSSION}

This study revealed that $68.8 \%$ of the students skipped meals and the breakfast was the meal mostly skipped (40.4\%). The skipping of breakfast has been associated with lower nutritional status and the risk of cardiovascular diseases [12]. It has also been reported that less adequate breakfast habits may contribute to the appearance and further development of obesity [13]. Therefore, the importance of regular eating patterns cannot be overemphasized in nutritional education. 


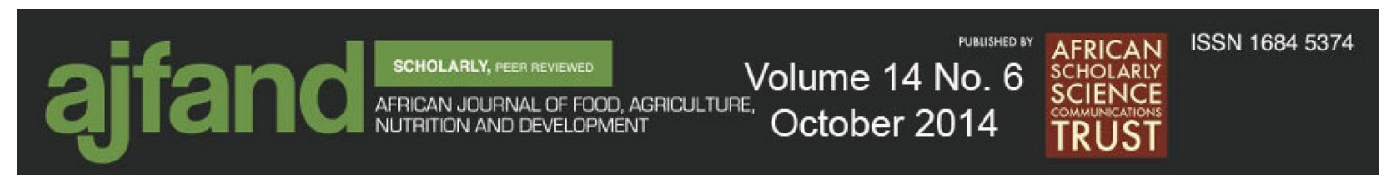

Generally, $71 \%$ of the students performed poorly. Poor nutrition knowledge among school students in rural QwaQwa, South Africa has also been reported by OldewageTheron and Egal [6]. This showed that the students were deficient in knowledge and understanding of the facts about energy and nutritive values of foods. Kostanjevec et al. [14] reported a similar observation among school students in Slovenia. This however, validates the need for adequate nutrition education at the secondary school level, which will go a long way to enhance the ability of the students to make good food choices and will positively influence their eating habits thereby ensuring better nutritional status. Numerous studies have shown that well-planned nutrition education can significantly influence the quality of nutrition knowledge of children $[15,16,17$, 18]. Nutrition education, which may take various forms of formal and informal education, can also significantly change nutrition behaviour and dietary habits of school children $[19,20,21]$.

Understanding different factors which influence nutrition behaviour of children is the first step to forming efficient measures which may change nutrition behaviour [22]. Education as well as nutrition knowledge, do not always have direct impact on nutrition behavior of individuals; however, they may significantly influence the attitudes, and other psychosocial factors which directly influence nutrition behaviour $[23,24]$. Worsley [21] believes that nutrition education is necessary; however, it is not the only factor which can change nutrition behaviour of persons. Harnack et al. [25] stress that nutrition education is a key element to promoting lifelong healthy eating and should start at early stages of life. Nutrition education is an accessible effective tool in the promotion of health nutrition in education programmes with focus on healthy eating $[26,27]$.

School nutrition education should focus not only on the provision of nutrition information, but also on the development of skills and behaviours related to areas such as food preparation, food preservation and storage; social and cultural aspects of food and eating; enhanced self-esteem and positive body image and other consumer aspects [28].

\section{CONCLUSION}

The poor nutrition education knowledge and nutritional status of the study population has revealed the need for adequate nutrition education intervention. Nutrition knowledge is needed for better dietary choices. Adolescents are becoming more autonomous and behavioural patterns acquired during this phase of life, such as dietary intake behaviour, may influence long-term behaviours. It is, therefore, recommended that a nutrition education programme be developed and implemented for this group of adolescents, as nutrition education can be an accessible and effective tool for improving food choices. Since most adolescents spend most of their time in school, school-based nutrition education, combined with physical activity programmes, can be employed to reinforce the message of healthy eating. 




Table 1: Food consumption and eating habits of the respondents

\begin{tabular}{|c|c|c|}
\hline & Frequency & Percent \\
\hline \multicolumn{3}{|l|}{ Frequency of eating per day } \\
\hline Once & 8 & 3.3 \\
\hline Twice & 32 & 13.3 \\
\hline Thrice & 135 & 56.3 \\
\hline More than 3 times & 65 & 27.1 \\
\hline Total & 240 & 100.0 \\
\hline \multicolumn{3}{|l|}{ Meal skipping } \\
\hline Yes & 165 & 68.8 \\
\hline No & 75 & 31.3 \\
\hline Total & 240 & 100.0 \\
\hline \multicolumn{3}{|l|}{ Reason for meal skipping } \\
\hline I don't like the food & 36 & 15.0 \\
\hline Fasting for religious reason & 137 & 57.1 \\
\hline No time to eat & 15 & 6.3 \\
\hline Just a habit & 49 & 20.4 \\
\hline To maintain my figure & 3 & 1.3 \\
\hline Total & 240 & 100.0 \\
\hline \multicolumn{3}{|l|}{ Meal skipped } \\
\hline Breakfast & 97 & 40.4 \\
\hline Lunch & 63 & 26.3 \\
\hline Dinner & 52 & 21.7 \\
\hline Breakfast and Lunch & 19 & 7.9 \\
\hline Lunch and Dinner & 9 & 3.8 \\
\hline Total & 240 & 100.0 \\
\hline \multicolumn{3}{|l|}{ Snacking } \\
\hline Yes & 197 & 82.1 \\
\hline No & 43 & 17.9 \\
\hline Total & 240 & 100.0 \\
\hline \multicolumn{3}{|l|}{ Reason for snacking } \\
\hline I like them & 116 & 48.3 \\
\hline Hunger & 63 & 26.3 \\
\hline Habit & 33 & 13.8 \\
\hline To make up for skipped meal & 28 & 11.6 \\
\hline Total & 240 & 100.0 \\
\hline \multicolumn{3}{|l|}{ Source of snack } \\
\hline School premises & 73 & 30.4 \\
\hline Home & 80 & 33.3 \\
\hline Outside school premises & 45 & 18.8 \\
\hline Food vendors & 42 & 17.5 \\
\hline Total & 240 & 100.0 \\
\hline
\end{tabular}




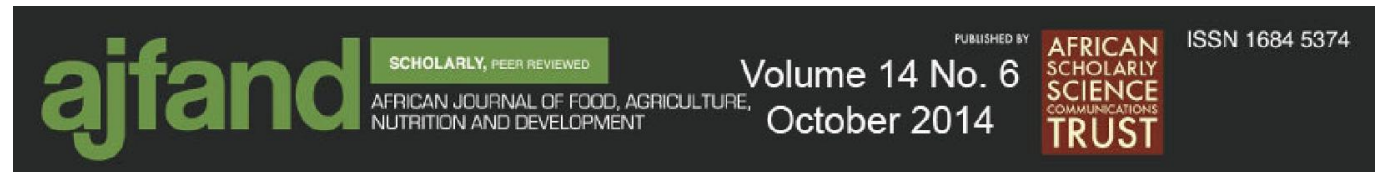

Table 2: Mean anthropometric values of selected secondary school students in Sokoto Metropolis

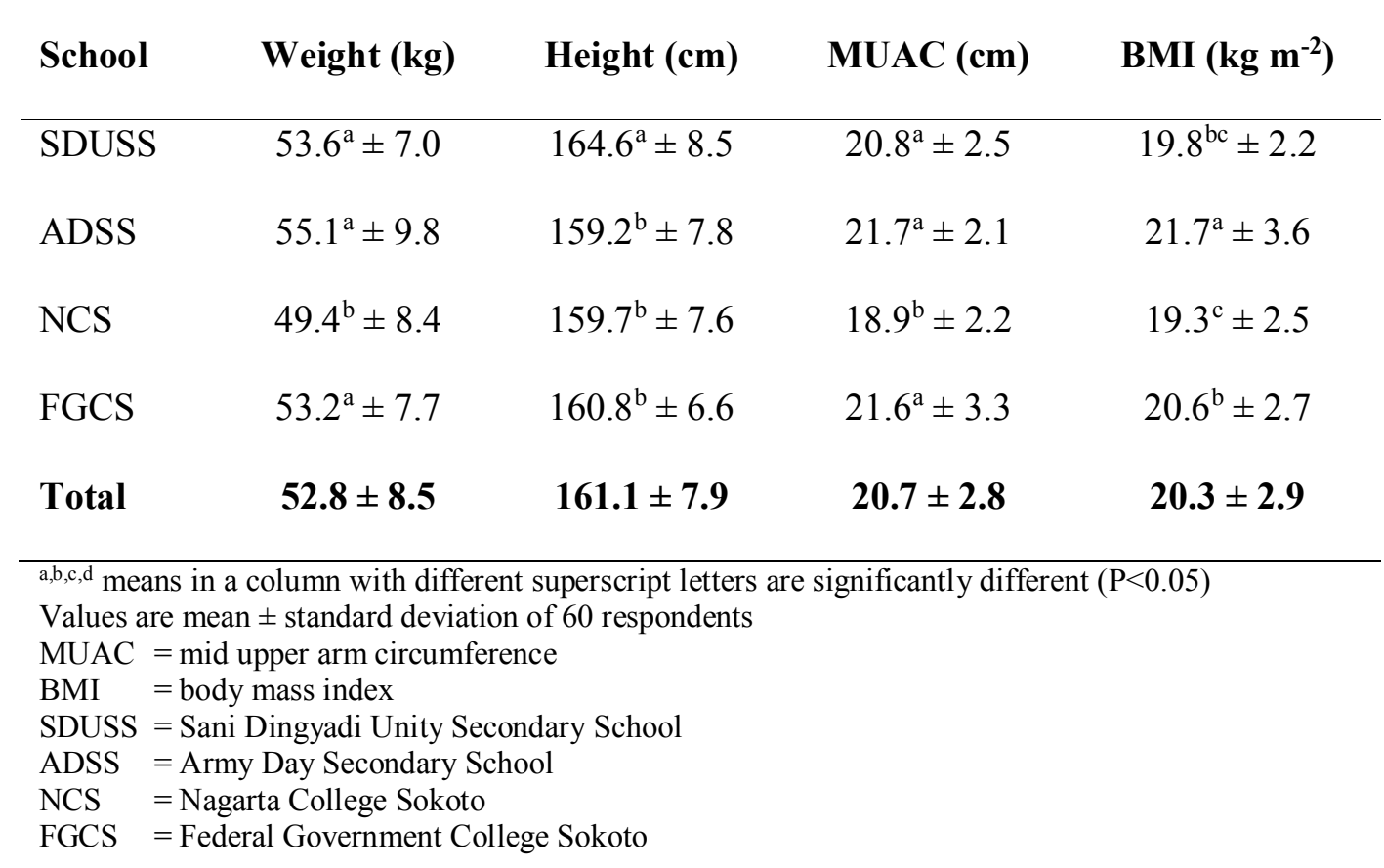






Table 3: Nutritional status of the respondents by age and sex

\begin{tabular}{|c|c|c|c|}
\hline & Underweight & Normal & Overweight \\
\hline \multicolumn{4}{|l|}{ Sex } \\
\hline Male & $57(33.9)$ & $104(61.9)$ & $7(4.2)$ \\
\hline Female & $10(13.89)$ & $51(70.83)$ & $11(15.28)$ \\
\hline \multirow[t]{2}{*}{ Total } & $67(27.92)$ & $155(64.58)$ & $18(7.50)$ \\
\hline & \multicolumn{3}{|c|}{ Chi-square $=16.169, p=0.000$} \\
\hline \multicolumn{4}{|c|}{ Age group (years) } \\
\hline $12-15$ & $18(32.1)$ & $33(58.9)$ & $5(8.9)$ \\
\hline $16-19$ & $41(27.3)$ & $98(65.3)$ & $11(7.3)$ \\
\hline $20-23$ & $8(23.5)$ & $24(70.6)$ & $2(5.9)$ \\
\hline Total & $67(27.92)$ & $155(64.58)$ & $18(7.50)$ \\
\hline & \multicolumn{3}{|c|}{ Chi-square $=1.368, p=0.850$} \\
\hline
\end{tabular}




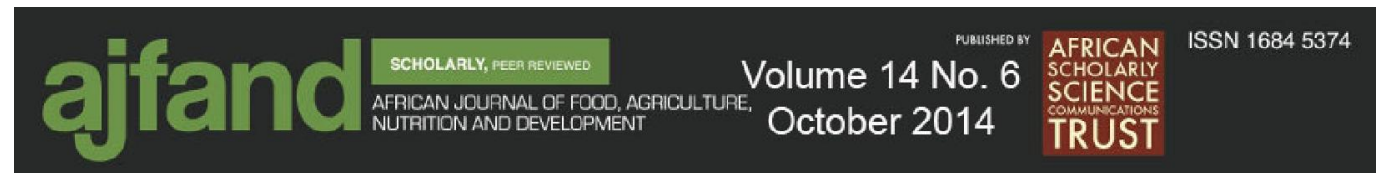

Table 4: Performance of the selected secondary school students in Sokoto Metropolis based on the Nutrition knowledge assessment

\begin{tabular}{|c|c|c|c|c|c|c|c|c|}
\hline \multirow{2}{*}{$\begin{array}{l}\text { Nutrition } \\
\text { knowledge } \\
\text { questions }\end{array}$} & \multirow{2}{*}{ Answers } & \multicolumn{4}{|c|}{ School } & \multirow[b]{2}{*}{ Total } & \multirow[b]{2}{*}{$\chi^{2}$} & \multirow[b]{2}{*}{ P-value } \\
\hline & & SDUSS & ADSS & NCS & FGCS & & & \\
\hline \multirow{3}{*}{$\begin{array}{l}\text { 1. Fruits are richest } \\
\text { in? }\end{array}$} & Wrong & $34(56.7)$ & 16 & $16(26.7)$ & $6(10.0)$ & $72(30.0)$ & 32.381 & $0.000 * *$ \\
\hline & & & $(26.7)$ & & & & & \\
\hline & Correct & $26(43.3)$ & $\begin{array}{c}44 \\
(73.3)\end{array}$ & $44(73.3)$ & $\begin{array}{c}54 \\
(90.0)\end{array}$ & $168(70.0)$ & & \\
\hline \multirow{3}{*}{$\begin{array}{l}2 . \text { Green leafy } \\
\text { vegetables contain } \\
\text { more of? }\end{array}$} & Wrong & $51(85.0)$ & 51 & $53(88.3)$ & 43 & $198(82.5)$ & 6.811 & 0.078 \\
\hline & & & $(85.0)$ & & $(71.7)$ & & & \\
\hline & Correct & $9(15.0)$ & $9(15.0)$ & $7(11.7)$ & $\begin{array}{c}17 \\
(28.3)\end{array}$ & $42(17.5)$ & & \\
\hline \multirow{4}{*}{$\begin{array}{l}\text { 3. Why is variety of } \\
\text { food in well-balanced } \\
\text { diet preferred to } \\
\text { eating a single kind } \\
\text { of food? }\end{array}$} & Wrong & $56(93.3)$ & 39 & $45(75.0)$ & 17 & $157(65.4)$ & 59.581 & $0.000 * *$ \\
\hline & & & $(65.0)$ & & $(28.3)$ & & & \\
\hline & Correct & $4(6.7)$ & 21 & $15(25.0)$ & 43 & $83(34.6)$ & & \\
\hline & & & $(35.0)$ & & (71.7) & & & \\
\hline \multirow{4}{*}{$\begin{array}{l}\text { 4. The food you eat } \\
\text { have effect on your } \\
\text { looks }\end{array}$} & Wrong & $12(20.0)$ & 18 & $19(31.7)$ & 16 & $65(27.1)$ & 2.429 & 0.489 \\
\hline & & & $(30.0)$ & & $(26.7)$ & & & \\
\hline & Correct & $48(80.0)$ & 42 & $41(68.3)$ & 44 & $175(72.9)$ & & \\
\hline & & & $(70.0)$ & & (73.3) & & & \\
\hline \multirow{2}{*}{$\begin{array}{l}\text { 5. Meat, fish, egg are } \\
\text { rich in? }\end{array}$} & Wrong & $36(60.0)$ & $5(8.3)$ & $12(20.0)$ & $2(3.3)$ & $55(22.9)$ & 67.247 & $0.000 * *$ \\
\hline & Correct & $24(40.0)$ & $\begin{array}{c}55 \\
(91.7)\end{array}$ & $48(80.0)$ & $\begin{array}{c}58 \\
(96.7)\end{array}$ & $185(77.1)$ & & \\
\hline \multirow{2}{*}{$\begin{array}{l}\text { 6. What should be } \\
\text { considered most } \\
\text { while choosing food? }\end{array}$} & Wrong & $56(93.3)$ & $\begin{array}{c}16 \\
(26.7)\end{array}$ & $40(66.7)$ & $\begin{array}{c}12 \\
(20.0)\end{array}$ & $124(51.7)$ & 86.229 & $0.000 * *$ \\
\hline & Correct & $4(6.7)$ & $\begin{array}{c}44 \\
(73.3)\end{array}$ & $20(33.3)$ & $\begin{array}{c}48 \\
(80.0)\end{array}$ & $116(48.3)$ & & \\
\hline \multirow{3}{*}{$\begin{array}{l}\text { 7. Eating too much of } \\
\text { oily and fatty food } \\
\text { can lead to which of } \\
\text { these health } \\
\text { problems? }\end{array}$} & Wrong & $38(63.3)$ & $\begin{array}{c}38 \\
(63.3)\end{array}$ & $47(78.3)$ & $\begin{array}{c}35 \\
(58.3)\end{array}$ & $158(65.8)$ & 6.002 & 0.112 \\
\hline & Correct & $22(36.7)$ & 22 & $13(21.7)$ & 25 & $82(34.2)$ & & \\
\hline & & & $(36.7)$ & & (41.7) & & & \\
\hline \multirow{2}{*}{$\begin{array}{l}\text { 8. Raw eggs are more } \\
\text { nutritious than } \\
\text { cooked eggs }\end{array}$} & Wrong & $47(78.3)$ & $\begin{array}{c}45 \\
(75.0)\end{array}$ & $47(78.3)$ & $\begin{array}{c}39 \\
(65.0)\end{array}$ & $178(74.2)$ & 3.740 & 0.291 \\
\hline & Correct & 13 (21.7) & $\begin{array}{c}15 \\
(25.0)\end{array}$ & $13(21.7)$ & $\begin{array}{c}21 \\
(35.0)\end{array}$ & $62(25.8)$ & & \\
\hline $\begin{array}{l}\text { 9. Healthy eating } \\
\text { should be combined }\end{array}$ & Wrong & $38(63.3)$ & $\begin{array}{c}40 \\
(66.7)\end{array}$ & $39(65.0)$ & $\begin{array}{c}28 \\
(46.7)\end{array}$ & $145(60.4)$ & 6.464 & 0.091 \\
\hline
\end{tabular}




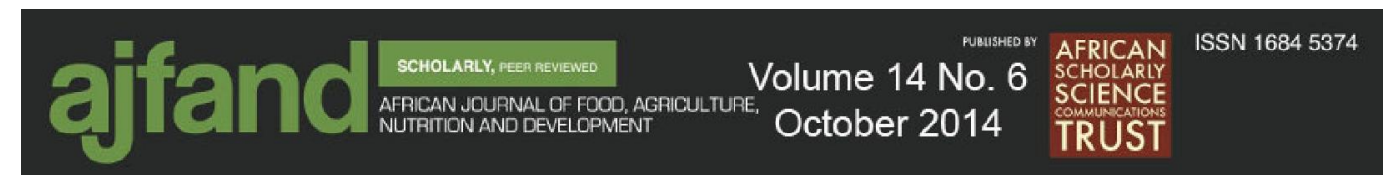

\begin{tabular}{lccccccc}
\hline $\begin{array}{l}\text { with what for better } \\
\text { health? }\end{array}$ & Correct & $22(36.7)$ & 20 & $21(35.0)$ & 32 & $95(39.6)$ \\
& & $(33.3)$ & & $(53.3)$ & \\
\end{tabular}

** Performance of students in selected schools differ significantly $(P<0.01)$

Values in parenthesis are percentages 


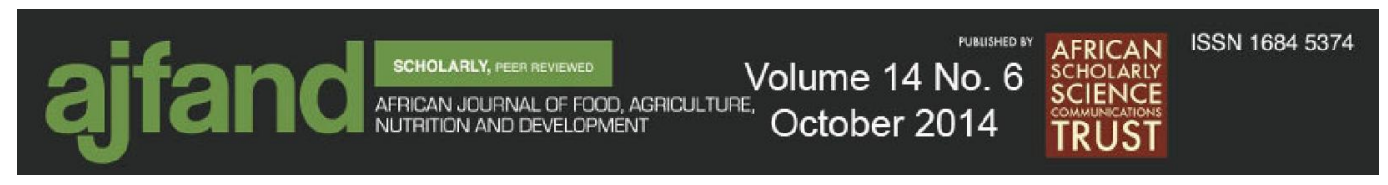

\section{REFERENCES}

1. Kris-Etherton PM Dietary advice and practice. In: Unilever Health Institute. The healthy choice, an easy choice. Vlaardingen: Unilever Health Institute. 2004: 18-22.

2. Sharma SV, Gernand AD and RS Day Nutrition knowledge predicts eating behaviour of all food groups except fruits and vegetables among adults in the Paso del Norte region: Que Sabrosa Vida. JNEB 2008; 40 (6): 361-368.

3. Contento $\mathbf{R}$ Nutrition education: linking research, theory and practice. Sudbury Massachusetts: Jones and Bartlett Publishers, 2007.

4. American Dietetic Association. Position of the American Dietetic Association: child and adolescent nutrition assistance programs. ADA 2010; 110 (5): 791-799.

5. Story M, Lytle LA, Birnbaum AS and CL Perry Peer-led, school-based nutrition education for young adolescents: feasibility and process evaluation of the TEENS study. J. Sch. Health. 2002; 72 (3): 121-127.

6. Oldewage-Theron WH and AA Egal Nutrition knowledge and nutritional status of primary school children in QwaQwa. SAJCN 2010; 23 (3): 149-154.

7. Wardle $\mathbf{J}$, Parmenter $\mathbf{K}$ and $\mathbf{J}$ Waller Nutrition knowledge and food intake. Appetite. 2000; 34: 269-275.

8. Wenhold F, Kruger S and E Muehlhof Nutrition for school-age children and adolescents. In: Steyn NP, Temple N (Eds). Community nutrition textbook for South Africa: a rights-based approach. Cape Town: Chronic Diseases of Lifestyle Unit, MRC. 2008: 441-478.

9. Walsh CM, Dannhauser A and G Joubert Impact of a nutrition education programme on nutrition knowledge and dietary practices of lower socioeconomic communities in the Free State and Northern Cape. SAJCN 2003; 16 (3): 89-95.

10. WHO. World Health Organization Measuring change in nutritional status. Guidelines for assessing the nutritional impact of supplementary feeding programmes for vulnerable groups, Geneva, 1983.

11. UNICEF. United Nations Children Education Fund The State of the World's Children. Focus on Nutrition. New York: Oxford University Press. 1998: 1011 . 


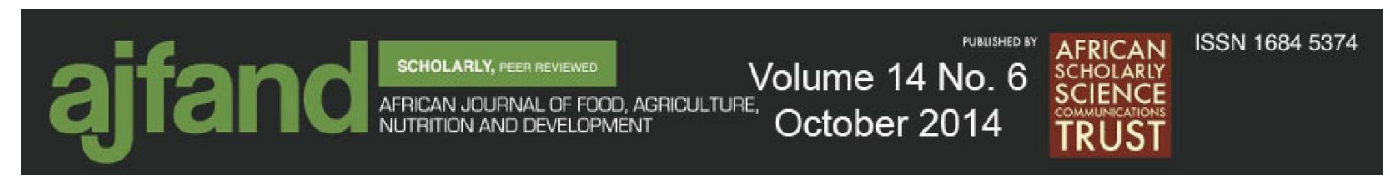

12. Sakata K, Matumura Y, Yoshimura N, Tamaki J, Hashimoto T and S Oguri Relationship between skipping breakfast and cardiovascular disease risk factors in the national nutrition survey data. Nippon Koshu Eisei Zasshi. 2001; 48: 837-41.

13. Ortega RM, Redondo MR, Lopez-Sobaler AM, Quintas ME, Zamora MJ and $\mathbf{P}$ Andres Associations between obesity, breakfast-time food habits and intake of energy and nutrients in a group of elderly Madrid residents. $J$. Am. Coll. Nutr. 1996; 15: 65-72.

14. Kostanjevec S, Jerman $\mathbf{J}$ and $\mathbf{V}$ Koch The effects of nutrition education on 6th graders knowledge of nutrition in nine-year primary schools in Slovenia. Eurasia J. Math Sci. Tech. Educ. 2011; 7 (4): 243-252.

15. Manios $\mathbf{Y}$ and $\mathbf{A}$ Kafatos Health and nutrition education in elementary Schools: Changes in health knowledge, nutrient intakes and physical activity over a six year period. Pub. Health Nutr. 1999; 2 (3): 445-448.

16. McAleese JD and LL Rankin Garden-based nutrition education affects fruit and vegetable consumption in sixth-grade adolescents. J. Am. Dietetic Assoc. 2007; 107: 662-665.

17. Powers A, Struempler B, Guarino A and S Parmer Effect of a nutrition education program on the dietary behavior and nutrition knowledge of secondgrade and third-grade students. J. Sch. Health. 2005, 75 (4): 129-133.

18. Wagner N, Meusel D and W Kirch Nutrition education for children - results and perspectives. J. Pub. Health. 2005; 13: 102-110.

19. Lytle L, Stone E, Nichaman M, Perry C, Montgomery D and T Nicklas Changes in nutrition intakes of elementary school children following a schoolbased intervention: results from the CATCH study. Prev. Med. 1996; 25: 465477.

20. Reynolds K, Winton A, Shewchuk R and C Hickey Social cognitive model of fruit and vegetable consumption in elementary school children. J. Nutr. Edu. Behav. 1999; 31 (1): 23-30.

21. Worsley A Nutrition knowledge and food consumption: can nutrition knowledge change food behavior? Asia Pacific J Clin Nutr. 2002; 11: 579585 .

22. Cullen KW, Rittenberry L, Olivera N and T Baranowski Environmental influences on children's diets: results from focus groups with African-, Euroand Mexican- American children and their parents. Health Edu. Res. 2000; 15: $581-590$. 


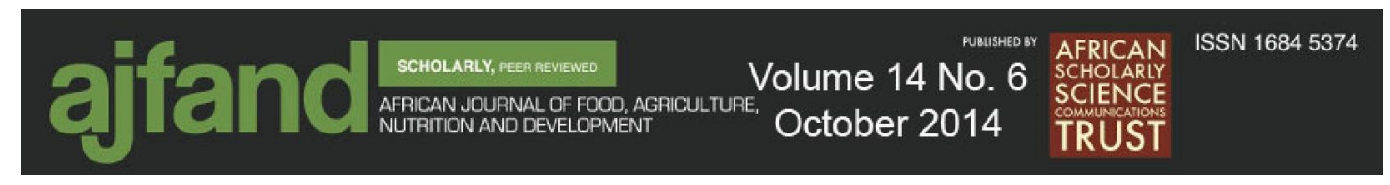

23. Conner M and C Armitage The social psychology of food. Buckingham, Open University Press. 2002: 12-42.

24. McCullough FS, Yoo $\mathbf{S}$ and $\mathbf{P}$ Ainsworth Food choice, nutrition education and parental influence on British and Korean primary school children. Int. J. Consumer Studies. 2004; 28 (3): 235-244.

25. Harnack L, Block $\mathbf{G}$ and $\mathbf{S}$ Lane Influence of selected environmental and personal factors on dietary behaviour and chronic disease prevention. J. Nutr. Edu. 1997; 29: 306-312.

26. Kelder S, Perry C, Lytle L and K Klepp Community-wide youth nutrition education: Long-term outcomes of the Minnesota Heart Health Program. Health Educ. Res. 1995; 10 (2): 119-131.

27. Torkar G, Pintarič M and V Koch Fruit and vegetable playing cards: utility of the game for nutrition education. Nutr. Food Sci. 2010; 40 (1): 74-80.

28. Perez-Rodrigo $\mathbf{C}$ and $\mathbf{J}$ Aranceta Nutrition education in schools: experiences and challenges. Eur. J. Clin. Nutr. 2003; 57 (1): 82-85. 